\title{
Mubalig Kondang: A Sociological Overview of Religiosity
}

\author{
Sukarjo Waluyo*1, Astri Adriani Allien² \\ 1Student of Doctoral Program of Literature, Faculty of Humanities, Indonesia University, Depok, Indonesia \\ ${ }^{2}$ Faculty of Humanities, Diponegoro University, Semarang, Indonesia
}

\begin{abstract}
The approach of literary sociology is one of the literary approaches that specialize in the study of literary works taking into account social aspects of society. Mubalig Kondang [1] is interesting to study because it tells how the author's expression of the religiosity problem that existed in the society of the Javaneses antri (students of traditional Islamic boarding school in Java) in particular, as well as Indonesia in general. Pengajian (mass teaching of Islam in the village) that becomes the habits and traditions of the santri community as well as the symbol of the author's heart disclosure. Pengajian is a common religious ritual around us still a kind of 'thing' that could be questioned. The religious ritualisonly a compensation of some people who are from the complexity of the problem.
\end{abstract}

Keywords: sociology of literature; santri society; religiosity; religious practice

\section{Introduction}

Literature is a social institution created by an author. Within social institutions there is a social order. Social institutions are a system of behaviour and norms to meet the needs of people's lives, including the life in a harmonious and low carbon society expected by everybody. In addition, literature displays a picture of life; and life is a social reality [2]. Literature can be used by authors to tell all the problems of human life in society. Literature is a description of the journey of human life when people come into contact with the events that occur in his life. It can be said that literature is a portrait of reality manifested through language [3]. Therefore, it can be said that literature is a product of life that contains the social and cultural values of human life phenomenon.

In the sociology of literature, literature is understood by considering the aspects of society. In addition, sought also the relationship of literature with the community behind it, and found a direct link between the literature with the community [4]. As a social institution created by the author, in the literature there are certain norms and rules that characterize an institution. The norms in society are the norms that govern the association of life with the aim to achieve an order. It exists in everysociety regardless of whether the society has a simple or modern culture [5]. One of the norms in society is religious norms. Religious norms are present in the midst of society because religion is a very important social institution in a religious society. Once the importance of religion, so that other norms at a later date are usually assimilated. It must even be subject to religious norms although in some cases it looks ambiguous [6]. The term religiosity looks more at the aspect "deep in the heart", the vibration of the private conscience; personal attitudes that are somewhat mysterious to others because they affirm the intimacy of the soul, $d u$ coeur in the Pascal sense, a taste that includes totality (including the ratio and the sense of humanity) the depth of the human person [7].

The short story of "Mubalig Kondang", partly as a social criticism [8], was written by Mustofa Bisri, a prominent Islamic, culturist, and author from Rembang, Central Java. His works are very well known in Indonesia and a representation of pesantren literature. The problem of this research is the religiosity of santri in short story of "Mubalig Kondang".

This research used structural and sociological approach. The principle of a structural approach is to expound carefully the elements and aspects of the literature that produce the overall meaning [9]. The sociological approach of literature specializes in

*Correspondingauthor: sukarjowaluyo@gmail.com 
studying literature taking into account social aspects [10]. Literature is an evaluative response to life; as a kind of mirror, literature reflects life after judging and fixing it [11]. As an imaginative result, in addition to being a fun entertainment, literature is also useful to add to the inner experience for the reader as well as the critic's device.

\section{Religiosity of Santri Expressed in Mubaliq Kondang}

Literature is authors processed that is from religious communities. It is therefore very relevant to discuss the relationship between religion and literature. In the next section then the literature talks must also talk about religion. The characteristics or circumstances that reflect the religious values that then result the term 'religiosities'. in their city will be the arrival of famous mubalig (Islamic preacher) from Jakarta. After sunset, wife and villagers with some vehicles started to leave the village to pengajian in their city.

Character 'I' ultimately went to pengajian in the city by riding an old bicycle. Along the way suddenly remembered the figure Sudin, his very bad friend while still a santri at a pesantren (traditional Islamic boarding school in Java). Sudin, because of his mischief, was sent by his wealthy father from the city to study at pesantren and to change his character.

Instead of getting better, in the pesantren, Sudin evenbe a 'trouble maker' by inviting character 'I' to leave the pesantren at night for the race by ridinga bike and watching a movie. Sudin was eventually evicted from pesantren known to have stolen the cash money of pesantren. Arriving at a very crowded pengajian, 'I' pushed through the crowd to get a closer look at the preacher who was giving the lecture. 'I' shocked, the preacher who was giving a lecture on stage was a figure he already knew that wasSudin.

Based on the results of the writer's reading, it appears that there are some religiosity values that appear in the short story of "Mubalig Kondang" by Mustofa Bisrithatis: first, the spirit of studying. It shows from character his wife and villagers who were very eager to study by attending various pengajian from village to village, as well as when there were many pengajian by famous mubalig in their city. In terms of background story, this short story shows the habits of Muslims in the area of santri, especially the santri community as expressed by the character 'I'. This isseenfrom the followingquote.

"Lo, Sampeyan ini bagaimana sih; kan nanti malam ada pengajian akbar?!” dia jatuhkan pantatnya yang tambun ke lincak bambu hingga
Social problems that are often implicit in many literature is responses to social phenomena and the complexity of the problems surrounding them. Literature is the product of society in the midst of society because it is formed by members of society based on emotional or rational urges from their society.

menimbulkan suara berderak; aku sedikit bergeser sambil berdoa mudah-mudahan lincak kesayanganku takambrol. "Orang sedesa upyek membicarakan dai kondang Ibu Kota yang akan mengisi pengajian nanti malam, kok Sampeyan tenang-tenangs aja. Makanya Sampeyan jadi orang mbok kumpul-kumpul. Jangan mengurung diri di rumah saja, seperti katak dalam tempurung!'”[1] p.19

Pengajian from one place to another becomes a part of the routine and form of worship and friendship in santri community. In a socio-cultural perspective may be seen as a form in order to build public space or also the means of catharsis. Even can also form actual and existence both personal and group. Sometimes in rural santri societies pengajian has the same function with the arts performances of the people. (Remember: how art functions in rural communities where art performances serve as a public space for communicating and gathering, means of education, the delivery of the intentions of certain groups, even find a mate, and economic motives). The excitedvillagers of 'I' also reflected by the following quotation.

"Ustaz bikin rombongan nyewa colt. Ibu-ibu juga bikin rombongan sendiri. Bu Lurah menyiapkan bus mini dan truk. Tadi saya sudah daftar dua orang. Kalau Sampeyan tidak pergi, biar nanti saya sama simbok. Ini pengajian akbar, mubalignya dari Jakarta. Kita mesti datang agak gasik supaya dapat tempat." [1) p. 19.

Pengajian is related to the problem of religiosity, also very much in accordance with the suggestion of Islamic religion such as: "God will raise the degree of those who studies", "God will pave the way for the affairs of people who study", "angels will flap their wings to seekers", "The Messenger of Allah (may peace be upon him) once privileged the wise men by not fighting", "the command of knowledge from the cradle to the grave", and "the command to study even though it must go to the land of China".

Second, berkhusnudzon (prejudiced both against others). In Islam there is the term 'khusnudzon' which means always prejudiced both on the fate that happens

*Correspondingauthor: sukarjowaluyo@gmail.com 
to us (which comes from God) and against others. This is represented by ' $\mathrm{I}$ ' when assessing Sudin, his very bad friend during the boarding school. The famous Mubalig isSudin, his old friend who behaves very naughty when being a santri eventually able to become a mubalig. This is seen in the followingquotation.

Apa tadi itu firasat? Baru di lamun, tiba-tiba ketemu! Sudin yang nakal. Sudin yang di pesantren langganan takzir. Sudin yang diusir karena mencuri uang kas pesantren. Ah, siapa mengira kini jadi mubalig kondang seperti itu. Bagaimana ceritanya Sudin sampai mempunyai karamah begitubesar? [1]

Relating to the problem of religiosity, it is also very much in accordance with the suggestion of the religion of Islam for example: "God'scues to not underestimate a people because may be people who are underestimatedeven more noble" and "many stories of Islamic teachings about bad people in the end be good because repentance, also vice versa ".

\section{Conclusion}

Mubalig Kondang is an interesting literature because it expresses the values of religiosity typical of Javanese and Indonesian santri. The author discusses the issue of religious practice in the community. The study is used as a symbol of the author's expression of hearts on religious issues, religious practices, and the substance of religious practice

\section{References}

1. AR. Sarjono (Ed.). BidadariSigar Rasa (Suara Jawa Tengah). DKJ. Jakarta. (2005)

2. S.D.Damono. Sosiologi Sastra. MIS Undip. Semarang. (2003)

3. M.A. Sardjono. PahamJawa. Pustaka Sinar Harapan Jakarta (1995)
Third, the concept of repentance. The amazement of 'I' who saw the figure of Sudin while speaking on the stage he connected with the repetance. Islamic teachings recognize that no leaf falls without the will of God. Nothing is impossible withGod, including human life. Many stories that show people who seem to deserve to go to hell, just go to heaven in the eyes of God. Relating to the problem of religiosity, also very appropriate with the suggestion of Islam religion for example: "a bitch who goes to heaven for giving drinking a dog thirsty", "the story of the murderer of one hundred people wholater repent", "people who are guaranteed by the Prophet Muhammad into heaven when he was ordinary people "(the person who does good to his mother, the one who always forgives the faults of others).

4. N.K. Ratna. Paradigma Sosiologi Sastra. Pustaka Pelajar. Yogyakarta (2003)

5. S. Soekanto. Sosiologi Suatu Pengantar. Rajawali .Jakarta ( 1988)

6. S. Waluyo. "Ambiguitas Sosial dalam Novel Pohon Tanpa Akar". .J. Alayasastra. 8, 1, 2012, Balai BahasaProvinsiJawaTengah, Badan Pengembangan dan Pembinaan Bahasa, Kemdikbud, Semarang. (2012) p. 55-63.

7. Y.B. Mangunwijaya. Sastra dan Relegiositas. Kanisius. Yogyakarta (1988)

8. S. Waluyo. "Novel Bukan Karena Kau Karya Toha Mohtar (SebuahTinjauan Sosiologis)" Tesis Magister Ilmu Susastra, Undip, Semarang (2010) p.5

9. A. Teeuw 1988. Sastra dan Ilmu Sastra.Gramedia. Jakarta (1988)

10. J. Sumardjo dan Saini K.M. Apresiasi Kesusastraan. Gramedia. Jakarta (1984)

11.S.D.Damono. "Kita dan Sastra Dunia." SN Bahasa, Sastra, dan Budaya: FIB.Undip, Semarang. (200

$\overline{\text { *Correspondingauthor: sukarjowaluyo@gmail.com }}$ 